International Journal of Agriculture, Environment and Bioresearch

Vol. 5, No. 03; 2020

ISSN: $2456-8643$

\title{
PHENOLOGICAL RESPONSES OF SOME CANOLA (Brassica napus ) GENOTYPES TO TEMPERATURE REGIMES DURING REPRODUCTIVE DEVELOPMENT
}

\author{
Nwogha $^{1,2}$ J. S., Agenbag ${ }^{1}$ G. A., Amadi ${ }^{2}$ C. O., Obidiegwu' ${ }^{2}$ J. E. and Oselebe, H. O ${ }^{3}$ \\ ${ }^{1}$ Department of Agronomy, University of Stellenbosch, South Africa \\ ${ }^{2}$ National Root Crops Research Institute, Umudike, Nigeria \\ ${ }^{3}$ Ebonyi State University, Abakaliki, Nigeria \\ https://doi.org/10.35410/IJAEB.2020.5504
}

\begin{abstract}
The objective was to screen some canola genotypes for heat tolerance and possible selection of heat tolerant genotypes for planting at more tropical South Africa regions. The study was conducted for two years in glass house of department of Agronomy, University of Stellenbosch South Africa. Randomized complete block design was used. Seven canola genotypes selected from early and mid-maturing groups of canola genotypes presently planted in the Western Cape, South Africa canola production area were grown in 3 litre plastic bags filled with a mixture of sand and compost at ratio of $1: 1$ and irrigated with fully balanced nutrient solution at $\mathrm{EC}=2.0$ in two glasshouses at night/day temperature regimes of $10 / 15^{\circ} \mathrm{C}$ and $15 / 20^{\circ} \mathrm{C}$. Number of days, growing degree days (GDD) and photothermal units (PTU) from planting to visible flower buds appearance, first flower opening, seed ripening and seed physiological maturity were recorded. Plants were sampled for leaf area (LA) and above ground dry mass (DM) at budding, flowering and seed physiological maturity stages. Days after planting, GDD and PTU at budding, flowering and physiological maturity were correlated with leaf area, dry mass, number of pods plant- 1 and pod dry mass plant-1 at budding, flowering and physiological maturity stages to determine whether there were relationships between the variables. The results showed that increasing daily mean temperature from $12.5^{\circ} \mathrm{C}$ to $17.5^{\circ} \mathrm{C}$, on average, reduced the duration of flowering time by 10.38 days, time to beginning of seed-filling by 25.39 days and from planting to physiological maturity by 28.09 days. However, there were variations among canola genotypes with regard to heat tolerance. These reductions in the duration may however change if plants were grown at different day lengths. Increased GDD and PTU due to higher mean daily temperatures decreased the total above ground dry mass, number of pods plant- 1 and pods dry mass at final harvest.
\end{abstract}

Keywords: Temperature, Canola, Phenology, Reproductive, Genotypes.

\section{INTRODUCTION}

Canola (Brassica napus) is increasingly becoming an important field crop in South Africa. It can be used to produce high quality cooking oil and margarine, animal feed, biofuel (Anonymous 2006) and in crop rotation systems to break the disease chain and improve weed management (Burton et al., 2008). In Canada, about 7.4 million ha of canola were grown at the great-plains province during 2009 (Statistics Canada 2010). In Australia two million hectares were sown to canola in 1999 but declined to half that due to drought in early years of this millennium. 
Vol. 5, No. 03; 2020

ISSN: $2456-8643$

Recently it however recovered to 2.69 million ha in 2012 (www.Australian oilseed federation 2013). Oil from canola seed is low erucic acid content (Anonymous 2006).

In Canada canola is planted in late April or early May, where-after it grows rapidly during the short summer season that has long warm days and is harvested in end September or early October. Although canola will flower much sooner at daylight lengths of 16 to 18 hours, it will eventually also flower at much shorter daylight lengths but after a longer period, (Kirkegaard et al., 2012). In South Africa and Australia canola is also planted in April or May but the growth take place during winter period with daylight lengths of $9.5 \mathrm{hrs}$ in May to $12 \mathrm{hrs}$ in September and is harvested during October. The phenological development affects the success of canola production and is largely controlled by temperature (Morrison et al., 1992). Accurate timing of these phenological events is generally considered the most important factor determining crop adaptation and maximum yield in a particular environment (Fischer 1979, Richard 1991).

In general development of an annual crop from emergence to maturity can be divided into three major phenological developmental phases: from emergence to flower buds initiation-vegetative development, from floral buds initiation to anthesis-reproductive development and from anthesis to physiological maturity -seed filling (Craufurd and Qi 2001, Ritchie 1991, Siebert and Ewert 2012). However, canola developmental stages can be divided into six phases according to Harper and Berkenkamp (1975): Phase 0-Pre-emergency, Phase 1-Seedling, Phase 2-Rosette, Phase 3stem elongation, Phase 4-flowering, Phase 5-Seed maturation. Under climate change scenario, increase in both the mean and extremes of temperature are expected for many parts of the world (IPCC 2001). These changes can impact largely on the growth and phenological development of crops. Temperature and to less extent photoperiod have been reported to be the major environmental factors that determine the timing and duration of each of the phenological phases in the physiological development of crops (Roberts et al., 1993). Many models have been developed to explain the phenological phases that take place during growth and development of crops (Alocija and Ritchie 1991, Matthews and Hunts 1994), while the physiological mechanisms that govern the transition from one phenophase to another are strongly influenced by environmental factors and have been described using photothermal models (Summerfield et al., 1991).

Photoperiod has been reported to be the principal factor that determines the time of floral initiation and hence anthesis date in many crop species (Burtero et al. 1999). Photoperiod, for example affects floral development of rice (Oryza sativa L.) (Coolhaas and Wormer 1953), caryopteris (Piringer et al., 1963), wheat( Triticum aestivum L.) (Slafer and Rawson 1994), barley (Hordeum vulgare L.) (Kernich et al., 1996) and quinoa (Chenopodium quinoa willd) (Burtero et al., 1999). However, it is not clear whether the duration of the reproductive phase is affected directly (immediate response) by the photoperiod experienced during this phase or indirectly (delayed response) by photoperiod experienced in earlier developmental phases. The delayed effects on reproductive development could be because of the fact that more leaf primordial are formed under an extended duration of the vegetative period and this means that anthesis has to wait longer because more leaves have to appear and all the leaves must appear before anthesis will occur (Kiniry et al., 1992). The underlined assumption here is that the total leaf number cannot be altered after the end of vegetative growth phase by transfer conduct 
Vol. 5, No. 03; 2020

ISSN: $2456-8643$

during anthesis and seed filling. However, Slafer and Rawson (1995) and Kernich et al.,(1996) have shown that time from the end of leaf appearance to anthesis is affected by the photoperiod after floral initiation, but not leaf number in wheat and barley respectively.

Ritchie and Smith (1991) reported that temperature regime is a major factor controlling the rate of leaf appearance. Hence "phyllochron" is defined as a constant interval of thermal time between successive leaves appearance. However the effect of temperature on the time interval between successive leaves' appearance (phyllochron) is crop specific for the different field conditions (Cao and Moss, 1989). For chenopodium photoperiod was reported to decrease the "plastochron" (the time between initiation of two successive primordia) with transfers from inductive to marginally or vice versa (Thomas, 1961). A photothermal duration effect on seed maturation processes has been demonstrated for soybean (Glycine max (L) merril), peanut (Arachis hypogeal L), bambaranut (Vigna subterrenea (L) verdc), rice (Oryza sativa), muccuna spp, maize (Zea mays L), sorghum (Sorghum bicolor) and field pea (Pisum sativum) ( Bagnall and King 1991; Birch et al., 1997; Craufurd and Qi 2001; Craufurd et al., 2003, Linnemam 1993; Morandi et al., 1998; Poggio et al., 2005 and Qi et al., 1998). It has also been reported that photothermal regime influence vernalisation sensitivity of crops. Plants vernalised for 50 days showed greater response to photoperiod than those vernalised for 15 days. As the duration of stem enlongation lengthened in photoperiod-sensitive genotypes by exposure to less inductive photoperiods, a higher number of fertile florets at anthesis are produced, leading to an increased grain number and thereby to higher yield (Gonzalez et al., 2003).

The timing of leaf emergence, flowering and seed filling as influenced by photothermal exposure and duration is critical in crop production, especially in the Mediterranean environment with its characteristic period of increasing temperatures and water stress that occur towards the end of the growing season. This study has not been conducted on canola because it is a relatively new crop in South Africa. This study was therefore conducted to determine the effect of temperature regimes on phenology of canola in order to enhance its agronomical management and maximally exploit its productive potentials under South African climatic conditions.

\section{MATERIALS AND METHODS}

The study was conducted in controlled glasshouse environment at department of Agronomy, University of Stellenbosch, South Africa. Experiment was laid out as a completely Randomized design (CRD) with two temperature regimes $\left(15 / 20^{\circ} \mathrm{C}\right.$ and $10 / 15^{\circ} \mathrm{C}$ night/day) and seven genotypes (Hyola $571 \mathrm{CL}$, AGAMAX, 45Y86, 44Y84, Hyola 50, 43Y85, and Hyola 575 CL) of canola as treatments. Four replications were used and single plant represents an experimental unit. Provision was made for three sampling times.

The seven genotypes of canola were planted (four seeds per 3 litre plastic bags filled with the mixture of sand and compost at ratio of 1:1 and irrigated with fully balance nutrient solution at $2.0 \mathrm{EC}$ ) in two glasshouses. The genotypes belonged to different maturity groups: $45 \mathrm{Y} 86$ and Hyola 50 (mid-maturing),44Y84 (mid-early) and 43Y85, AGAMAX, Hyola 571 CL and Hyola $575 \mathrm{CL}$ (early maturing). During the seedling stage, plants were thinned to one per bag. The plants were irrigated twice a day to re-fill the bags to field water capacity. 
Daylight length (number of hours of sunshine) was obtained from the South African weather service (http//www.Weathera.com). Crops were planted on 11 February 2014 and the final harvest was done on 14 July 2014 with the result that the day length varied between 13:20 hours at planting and 10:48 hours during the final harvest. The light intensity in the glasshouses and outside exposed environment were measured weekly at $12 \mathrm{~h} 00$ from the seedling stage of the plants and averages of $211.6 \mu \mathrm{molm}-2 \mathrm{~s}-1$ for $15 / 20^{\circ} \mathrm{C}$ glasshouse, $249.1 \mu \mathrm{molm}-2 \mathrm{~s}-1$ for $10 / 15^{\circ} \mathrm{C}$ glasshouse and $481.5 \mu \mathrm{molm}-2 \mathrm{~s}-1$ for outside environment were obtained. Temperature loggers were put in each glass house to record the actual temperature of the glass houses to make sure that the set temperatures were achieved.

The number of days required to reach the following growth stages (GS) according to Harper and Berkenkamp (1975) were recorded: visible inflorescence at center of rosette or budding (GS 3.1); first flower open (GS 4.1); beginning of seed filling) (GS 4.4); lower pods filled to full size and become translucent (GS 5.1); and seeds in lower pods turn brown which is physiological maturity (GS 5.4).

Number of days was multiplied by the mean of the set night/day temperatures $17.5^{\circ} \mathrm{C}$ for $15 / 20^{\circ} \mathrm{C}$ and $12.5^{\circ} \mathrm{C}$ for $10 / 15^{\circ} \mathrm{C}$ to calculate the growing degree days (GDD). While the growing degree days (GDD) $\mathrm{x}$ mean daylight length (sunrise to sunset) was used to compute the photothermal units (PTU) needed by different genotypes to reach the above described growth stages Plants in both glasshouses were sampled at the budding, full flowering and physiological maturity stages to determine the leaf area (LA) and dry mass (DM) aGer being oven dried for $48 \mathrm{hrs}$ at $80^{\circ} \mathrm{C}$. Number of pods plant-1 (NPP) was recorded at final harvest (physiological maturity) stage and pods dry mass (PDM) plant-1 were also obtained aGer oven drying the samples for $48 \mathrm{hrs}$ at $80^{\circ} \mathrm{C}$. Days aGer planting (DAP), GDD and PTU at budding, flowering and physiological maturing stages were correlated with LA, DM, NPP and PDM at budding, flowering and physiological maturing stages to determine whether there were relationships between the variables.

An appropriate analysis of variance (ANOVA) was performed, using Statistica soGware, version $12 \AA$. The Bonferroni test's least significant difference (LSD) values were calculated at the 5\% probability level to compare treatment means.

\section{RESULTS AND DISCUSSION BUDDING}

Budding stage is characterized by appearance of flower buds in the terminal region and stem elongation (Slauenwhite and Qaderi. 2013). Number of days, $\operatorname{GDD}\left({ }^{\circ} \mathrm{Cd}\right)$ and $\mathrm{PTU}\left({ }^{\circ} \mathrm{Cdhr}\right)$ required by the seven genotypes to budding stage from planting date in response to day/night temperature regimes of $10 / 15^{\circ} \mathrm{C}$ and $15 / 20^{\circ} \mathrm{C}$ is shown in Figure 3

At the lower temperature regime of $10 / 15^{\circ} \mathrm{C}$, genotypes required significantly a greater number of days from planting to budding stage than at the higher temperature regime of $15 / 20^{\circ} \mathrm{C}$ (Figure 3 ). At the $10 / 15^{\circ} \mathrm{C}$ temperature regime genotypes required about 42.5 days from planting to budding and Hyola 50, 44Y84, 43Y85 and 45Y86 were not significantly different from each, other but required significantly more days from planting to budding than other genotypes. At the $15 / 20^{\circ} \mathrm{C}$ temperature regime genotypes required about 38.71 days from planting to budding and 
Vol. 5, No. 03; 2020

ISSN: $2456-8643$

Hyola 50, 44Y84 and 43Y85 did not differ significantly, but required more days than other genotypes.

In contrast to number of days, genotypes required significantly more GDD at higher night/day temperature regime of $15 / 20^{\circ} \mathrm{C}$ than at the lower night/day temperature regime of $10 / 15^{\circ} \mathrm{C}$ (Figure 3b). On average $677.5^{\circ} \mathrm{Cd}$ were required by genotypes at the $15 / 20^{\circ} \mathrm{C}$ temperature regime. Similar to number of days Hyola 50, 44Y84 and 43Y85 were not significantly different to each other but required significantly more GDD than Hyola 571, Hyola 575, AGAMAX and $45 \mathrm{Y} 86$. At the $10 / 15^{\circ} \mathrm{C}$ temperature regime, genotypes required $529.91{ }^{\circ} \mathrm{Cd}$ on average from planting to budding. Hyola 50, 44Y84 and $43 \mathrm{Y} 85$ were not significantly different from each other but required significant more GDD than other genotypes.

Genotypes PTU requirements from planting to budding stage differ between the temperature regimes (Figure c). At the higher temperature regime of $15 / 20^{\circ} \mathrm{C}$ genotypes required significantly more PTU than at the lower temperature regime of $10 / 15^{\circ} \mathrm{C}$. On average $8398.59^{\circ} \mathrm{Cdhr}$ were required at the $15 / 20^{\circ} \mathrm{C}$ temperature regime from planting date to budding stage and there were no significant differences between genotypes. At the lower temperature regime $\left(10 / 15^{\circ} \mathrm{C}\right)$ genotypes required on average $4737.63^{\circ} \mathrm{Cdhr}$ from planting to budding stage with significant differences between genotypes. Hyola 575 and 43 Y 85 required significantly less PTU than other genotypes.

Increase in night/day temperatures from $10 / 15^{\circ} \mathrm{C}$ to $15 / 20^{\circ}$ resulted in reduced number of days, increased GDD and PTU from planting to budding stage. Except for PTU at the $15 / 20^{\circ} \mathrm{C}$, genotypes showed significant differences with regard to number of days, GDD or PTU required from planting to budding stage. In general, later maturing genotypes such as Hyola 50, 45Y86 and 44Y85 tend to need more days and GDD, but not PTU to reach the budding stage when compared to earlier maturing Hyolal575, Hyola 571 and AGAMAX. However cultivar 43Y85 which is classified as an early maturing cultivar responded in a similar way than later maturing genotypes. Angadi et al., (2000) similarly observed different responses for three Brassica species to temperatures of $20 / 15^{\circ} \mathrm{C}, 28 / 18^{\circ} \mathrm{C}$ and $35 / 15^{\circ} \mathrm{C}$ at the onset of the reproductive growth phase. Results agreed with the findings of Hartel (2012) who reported that canola grown under mean temperatures of $10.2^{\circ} \mathrm{C}$ and $13.2^{\circ} \mathrm{C}$ required 75 and 62 days from sowing to stem enlongation (budding) stage and subsequently accumulated $760^{\circ} \mathrm{Cd}$ and $747^{\circ} \mathrm{Cd}$ respectively. 


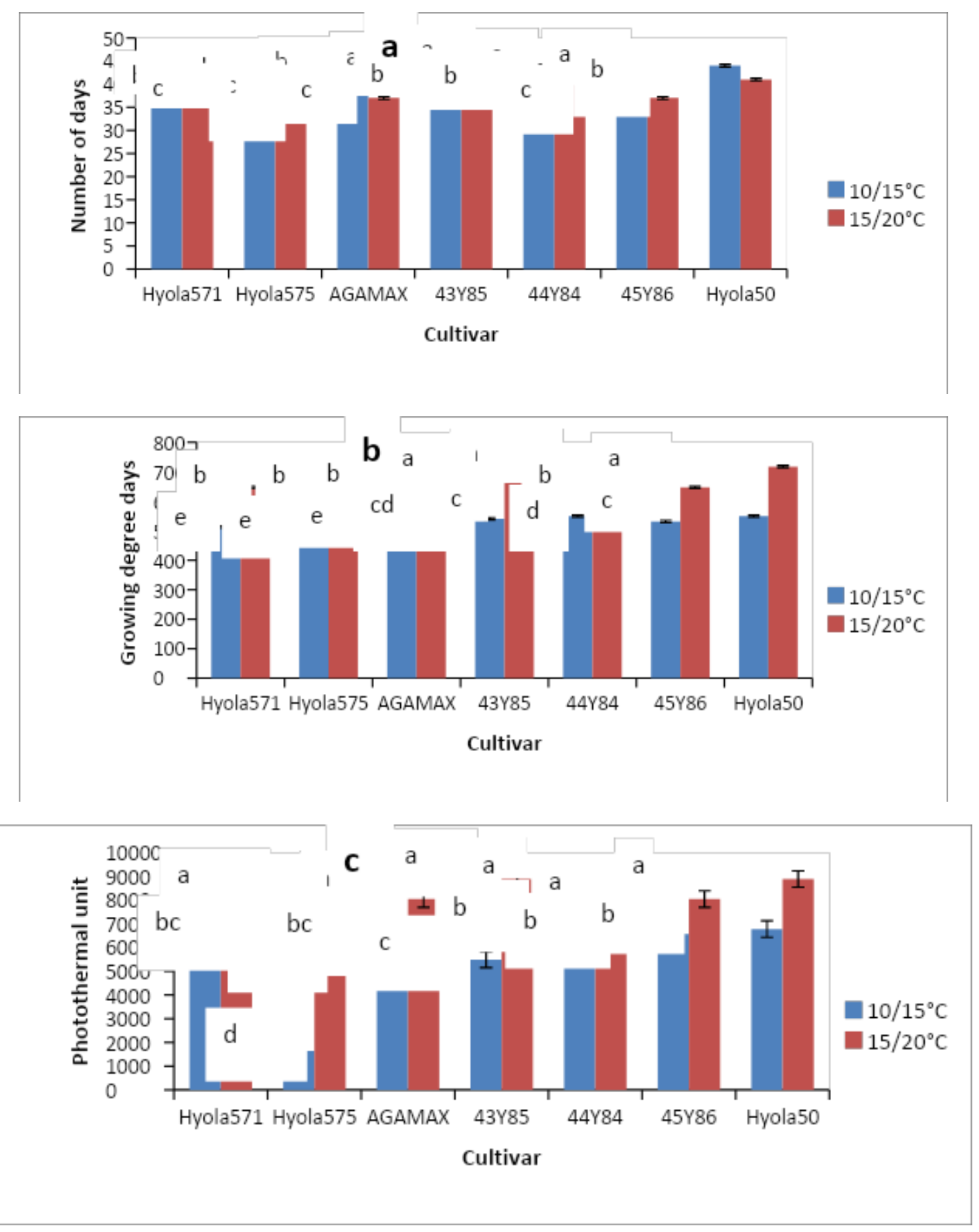

Figure 1. Effect of temperature on a) the number days, b) growing degree days $\left({ }^{\circ} \mathrm{Cd}\right)$ and c) photothermal units $\left({ }^{\circ} \mathrm{Cdh}\right)$ required from planting till the appearance of flower buds on the terminal stem region of different genotypes. Values/ bars with the same alphabetical lettering do not differ significantly at $\mathrm{P}=0.05$ 
Vol. 5, No. 03; 2020

ISSN: $2456-8643$

\section{Flowering}

Number of days, GDD and PTU required for all genotypes from planting to flowering (growth stage 4.1) in response to night/day temperature regimes of $10 / 15^{\circ} \mathrm{C}$ and $15 / 20^{\circ} \mathrm{C}$ are shown in Figure 4 .At the $10 / 15^{\circ} \mathrm{C}$ temperature regime genotypes required significantly more days from planting to flowering than at the $15 / 20^{\circ} \mathrm{C}$ temperature regime (Figure $4 \mathrm{a}$ ). At $10 / 15^{\circ} \mathrm{C}$ genotypes required 60.32 days on average to reach the flowering stage, but significant differences were noticed between genotypes. Hyola 50 did not require significantly more days than 44Y84, but required significantly more days to flower than other genotypes. At $15 / 20^{\circ} \mathrm{C}$, genotypes on average required 50 days from planting to flowering, genotypes 44Y84, Hyola 50, 43 Y85 and 45 Y86, required significantly more days to flower than other genotypes.

The GDD requirement from planting to flowering increased significantly with an increase in night/day temperature from $10 / 15^{\circ} \mathrm{C}$ to $15 / 20^{\circ} \mathrm{C}$ (Figure $4 \mathrm{~b}$ ). On average, $871.25^{\circ} \mathrm{Cd}$ were required at $15 / 20^{\circ} \mathrm{C}$ compared to $754.02^{\circ} \mathrm{Cd}$ at $10 / 15^{\circ} \mathrm{C}$. No significant differences were recorded at $15 / 20^{\circ} \mathrm{C}$ between genotypes, 44Y84, 43Y85, Hyola50 and $45 \mathrm{Y} 86$, but these genotypes required significantly more GDD from planting to flowering than Hyola 571, Hyola 575 and AGAMAX. At $10 / 15^{\circ} \mathrm{C}$, Hyola 50 required with the exception of $45 \mathrm{Y} 84$, significant more GDD from planting to flowering than other genotypes.

Similarly, PTU requirement from planting to flowering also increased with increase in night/day temperature from $10 / 15^{\circ} \mathrm{C}$ to $15 / 20^{\circ} \mathrm{C}$ (Figure $11 \mathrm{c}$ ). At higher temperatures of $15 / 20^{\circ} \mathrm{C}$ genotypes required on average $10651^{\circ} \mathrm{Cdhr}$ compared to $9096^{\circ} \mathrm{Cdh}$ at $10 / 15^{\circ} \mathrm{C}$. Genotypes Hyola 50 , 45Y86, 44Y84 and 43Y85, required significantly more PTU from planting to flowering than other genotypes at the higher temperature regime of $15 / 20^{\circ} \mathrm{C}$. At $10 / 15^{\circ} \mathrm{C}$, Hyola 571 required the lowest number of PTU and Hyola 50 the largest number of PTU to reach flowering stage.

Higher night/day temperature of $15 / 20^{\circ} \mathrm{C}$ reduced number of days but increased GDD and PTU needed to develop from planting to flowering when compared to a lower night/day temperature of $10 / 15^{\circ} \mathrm{C}$. Genotypes responded differently at each temperature regimes with respect to number of days, GDD and PTU needed to reach flowering stage. The rate of biochemical reactions, including those involved in flowering are generally speed up as temperature increases. Therefore, the reduction in number of days to flowering of 10.38 days on average at higher temperature regime compared to the lower temperature regime could be as a result of this catalytic acceleration of biochemical processes involved as also shown by quite a number of previous studies (Fitter and Fitter, 2002, Hepper 2003, Kaesha 2009). Robertson (2002) also reported that increased temperature between 12 and $20^{\circ} \mathrm{C}$ reduced number of days to flowering in 21 canola genotypes. Similar results were also reported by Tacarindua et al., (2013) for soybeans grown in a temperature gradient chamber.

On average, later maturing genotypes such as Hyola 50, 45Y86 and 44Y84 required more days, GDD and PTU to reach flowering stage than early maturing Hyola 471, Hyola 575 and AGAMAX. However, 43Y85 which is described as an early maturing cultivar but from a different breeding company, responded more like later maturing genotypes of the same breeding company. Robertson et al. (2002) reported that an early maturing canola type such as Monty required the range of 44-109 days to flowering, while mid maturing genotypes such as Hyola 42 
required from 44-118 days and late maturing Pinnacle required from 47-124 days to flower, depending on day length and soil fertility conditions. Similarly, Slauenwhite and Qaderi (2013) reported that there were significant differences between four canola genotypes with respect to number of days to flowering and GDD accumulated at flowering.

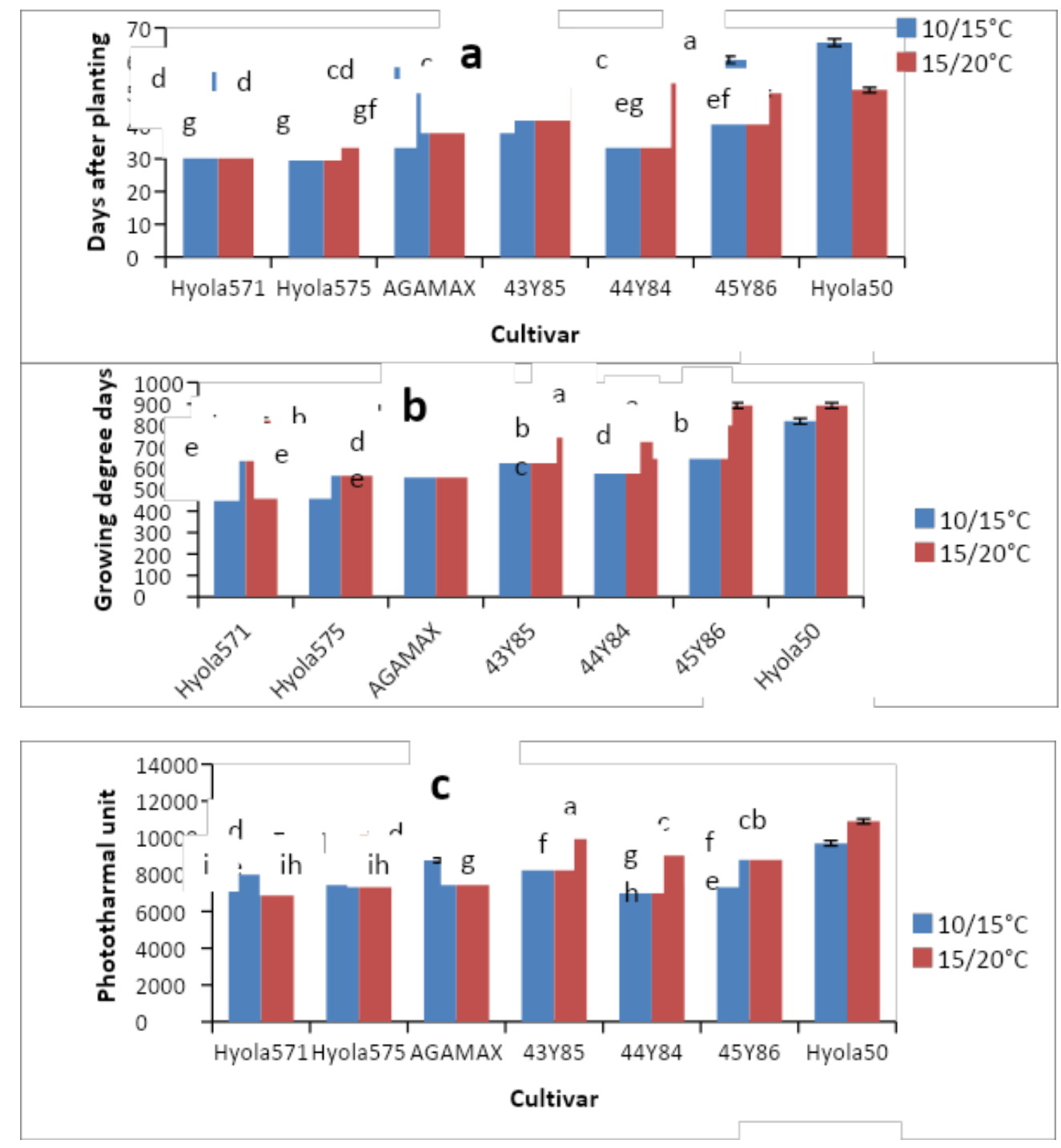

Figure 2. Effect of temperature on a) the number days, b) growing degree days $\left({ }^{\circ} \mathrm{Cd}\right)$ and $\mathrm{c}$ ) photothermal units $\left({ }^{\circ} \mathrm{Cdh}\right)$ required from planting till the opening of the flower buds of different genotypes. Values/ bars with the same alphabetical lettering do not differ significantly at $\mathrm{P}=0.05$

\section{Seed ripening}

Number of days after planting, GDD and PTU required by different genotypes grown at either $10 / 15^{\circ} \mathrm{C}$ or $15 / 20^{\circ} \mathrm{C}$ temperature regimes to reach the seed ripening stage (growth stage 5.1) are 
shown in Figure 5. Number of days from planting to seed ripening stage was significantly more when grown at $10 / 15^{\circ} \mathrm{C}$ compared to $15 / 20^{\circ} \mathrm{C}$ (Figure 5a). On the average, 102.42 days were required to reach seed ripening at the $10 / 15^{\circ} \mathrm{C}$ compared to 77.21 days at $15 / 20^{\circ} \mathrm{C}$ temperature regime. Significant differences between genotypes were recorded. Hyola 50, 44Y84 and 43 Y85 required more days at $10 / 15^{\circ} \mathrm{C}$ while $44 \mathrm{Y} 84$ and $45 \mathrm{Y} 86$ required significantly more days at $15 / 20^{\circ} \mathrm{C}$ to reach seed ripening stage than other genotypes.

With the exception of 43 Y85 and Hyola 50, all genotypes required significantly more GDD from planting to seed ripening at the $15 / 20^{\circ} \mathrm{C}$ temperature regime than at the $10 / 15^{\circ} \mathrm{C}$ temperature regime (Figure $5 \mathrm{~b}$ ). On average, $1347.64^{\circ} \mathrm{Cd}$ were required from planting to seed ripening at the $15 / 20^{\circ} \mathrm{C}$ temperature regime, with $44 \mathrm{Y} 84$ and $45 \mathrm{Y} 86$ requiring significantly more GDD than other genotypes. At the $10 / 15^{\circ} \mathrm{C}$ temperature regime genotypes required on average $1277.23^{\circ} \mathrm{Cd}$ to reach the seed ripening stage and with the exception of $43 \mathrm{Y} 85$ and $44 \mathrm{Y} 84$, Hyola 50 required significantly more GDD than other genotypes.

Similarly, with exception of $43 \mathrm{Y} 85$, PTU requirements for genotypes to reach the seed ripening stage were significantly more at $15 / 20^{\circ} \mathrm{C}$ at $10 / 15^{\circ} \mathrm{C}$ (Figure $5 \mathrm{c}$ ). On average $15347.7^{\circ} \mathrm{Cdhr}$ were required from planting to seed ripening at the $15 / 20^{\circ} \mathrm{C}$ temperature regime. Cultivar $44 \mathrm{Y} 84$, required significantly more PTU than other genotypes. At the $10 / 15^{\circ} \mathrm{C}$ temperature regime, $14108.23^{\circ} \mathrm{Cdhr}$ were required on average but Hyola 50, $44 \mathrm{Y} 84$ and $43 \mathrm{Y} 85$ required significantly more PTU than other genotypes.

The increase in night/day temperatures from $10 / 15^{\circ} \mathrm{C}$ to $15 / 20^{\circ} \mathrm{C}$ reduced the number of days and with the exception of $43 \mathrm{Y} 85$ and Hyola 50 increased GDD and PTU from planting to seed ripening. Although significant differences were recorded between genotypes and their responses to increasing night/day temperature, responses did not show a clear relationship with maturity grouping.

Hartel (2012) reported that the responses of crops to mean temperatures of $10.2^{\circ} \mathrm{C}$ and $13.2^{\circ} \mathrm{C}$ after the end of flowering were increased at a greater rate compared to before flowering.

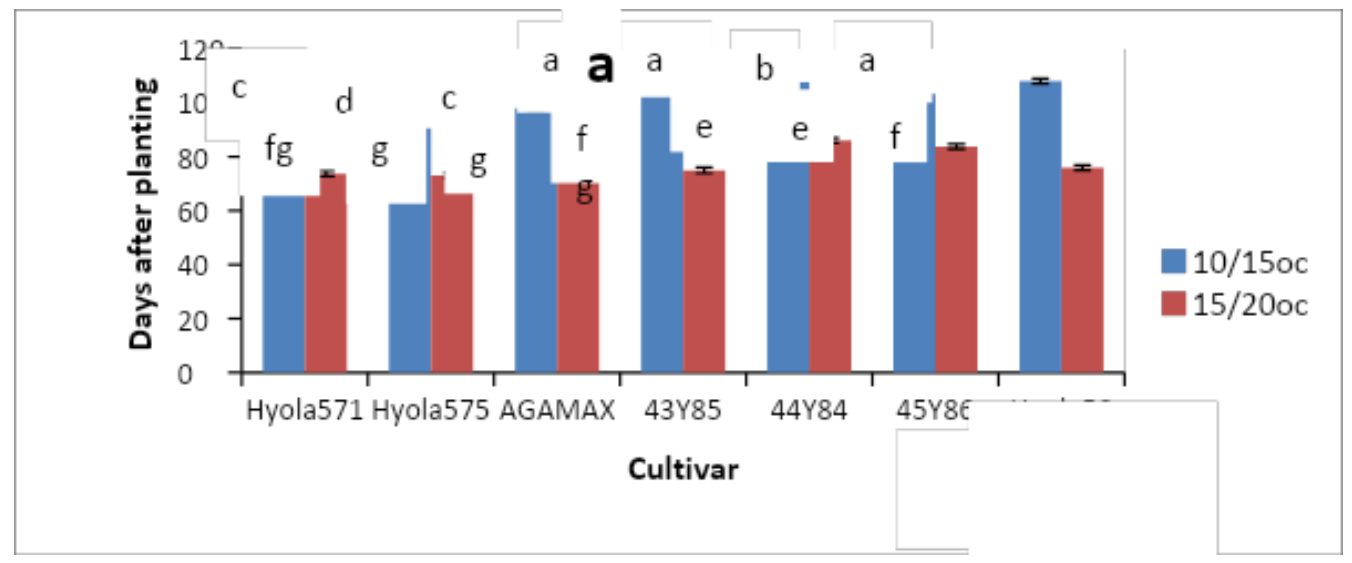


Vol. 5, No. 03; 2020

ISSN: 2456-8643

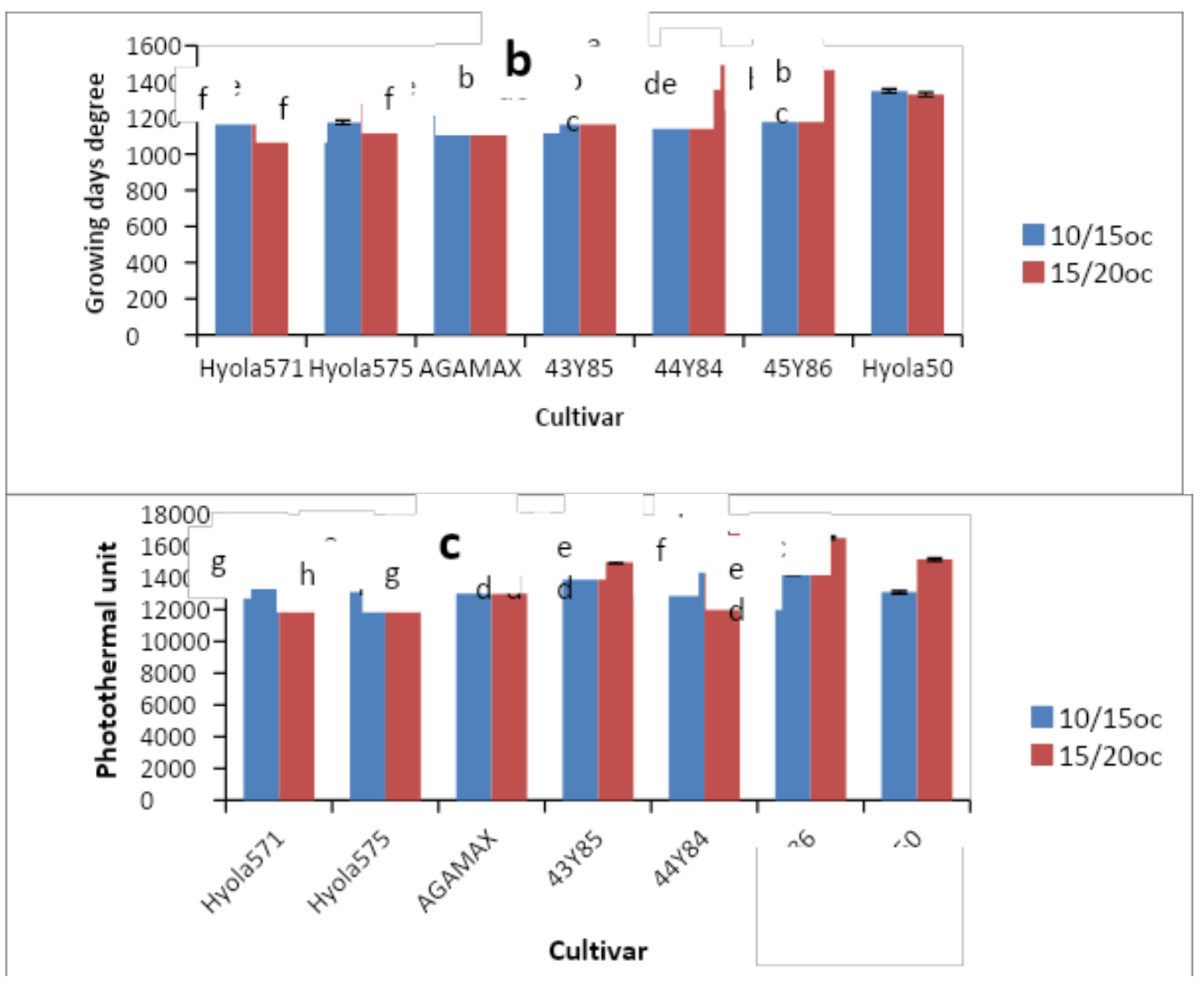

Figure 3. Effect of temperature on a) the number days, b) growing degree days $\left({ }^{\circ} \mathrm{Cd}\right)$ and c) photothermal units $\left({ }^{\circ} \mathrm{Cdh}\right)$ required from planting till seed ripening of different genotypes. Values/ bars with the same alphabetical lettering do not differ significantly at $\mathrm{P}=0.05$

\section{Physiological maturity}

Number of days, GDD and PTU required by genotypes from planting to physiological maturity at $10 / 15^{\circ} \mathrm{C}$ and $15 / 20^{\circ} \mathrm{C}$ temperature regime are shown by Figure 6 . Genotypes required significantly more days from planting to physiological maturity stage when grown at $10 / 15^{\circ} \mathrm{C}$ than at $15 / 20^{\circ} \mathrm{C}$ (Figure 6a). On average about 141.29 days were required from planting to physiological matured stage at a temperature of $10 / 15^{\circ} \mathrm{C}$, with cultivar $44 \mathrm{Y} 84$ requiring significantly more days than other genotypes. Hyola 50 and $45 \mathrm{Y} 86$ required more days than early maturing Hyola 571, Hyola 575, AGAMAX and $43 \mathrm{Y} 85$. At the $15 / 20^{\circ} \mathrm{C}$ temperature regime, 113.20 days were required on average, with a similar trend between genotypes except for no significant difference between $44 \mathrm{Y} 84$ and $45 \mathrm{Y} 86$.

In contrast to number of days, GDD requirement from planting to physiological maturity were significantly more at the $15 / 20^{\circ} \mathrm{C}$ temperature regime compared to $10 / 15^{\circ} \mathrm{C}$ (Figure $6 \mathrm{~b}$ ). On average genotypes required $1981.04^{\circ} \mathrm{Cd}$ from planting to physiological maturity at $15 / 20^{\circ} \mathrm{C}$. Differences do exist between genotypes, with 44Y84, with the exception of $45 \mathrm{Y} 86$, requiring 
Vol. 5, No. 03; 2020

ISSN: $2456-8643$

significantly more GDD than other genotypes. Hyola 50 also requires more GDD than early maturing Hyola 571, Hyola 575, AGAMAX and 43 Y 85. At the $10 / 15^{\circ} \mathrm{C}$ temperature regime genotypes required on average $1766.07^{\circ} \mathrm{Cd}$ from planting to physiological maturity and differences between genotypes showed a similar trend than for $15 / 20^{\circ} \mathrm{C}$.

The PTU requirement from planting to physiological maturity showed a similar trend than GDD with significantly more PTU required at $15 / 20^{\circ} \mathrm{C}$ than at $10 / 15^{\circ} \mathrm{C}$ (Figure $6 \mathrm{c}$ ). On average, $21811.29^{\circ} \mathrm{Cdhr}$ were required at the $15 / 20^{\circ} \mathrm{C}$ temperature regime. As in the case of GDD, 44Y84, with exception of 45Y86, required significantly more PTU than other genotypes, while Hyola 50 also required more PTU than early maturing Hyola 571, Hyola 575, AGAMAX and 43 Y85. Whereas, at the $10 / 15^{\circ} \mathrm{C}$ temperature regime, $18404.86^{\circ} \mathrm{Cdhr}$ were required on average and differences between genotypes were similar to that at the higher temperature regime. .

At physiological maturity an increase in night/day temperatures from $10 / 15^{\circ} \mathrm{C}$ to $15 / 20^{\circ} \mathrm{C}$ reduced number of days but increased GDD and PTU requirement of all genotypes tested. Significant differences were recorded between genotypes with mid maturing genotypes 44Y84, 45 Y85 and to a lesser extend also Hyola 50 requiring significantly more days, GDD and PTU from planting to reach physiological maturity than early maturing Hyola 272, Hyola 575, AGAMAX and 43 Y 85.

The same trends of genotypes responses to the two temperature regimes with regard to number of days, GDD and PTU were observed as at budding, flowering and seed ripening with the exception that cultivar 43 Y 85 which behave similar to mid maturing genotypes at earlier growth stages, suddenly confirms its classification as an early maturing cultivar. It is also noteworthy that this particular cultivar shared most of morphological and physiological characteristics of mid-maturing type but only seem to have a shorter pod filling period. Therefore it appeared that 43 Y85 has a unique physiological mechanism of rapid seed-filling and ripening processes which enabled it to catch up with early maturing genotypes after sharing the physiological trait(s) for lateness from germination to the beginning of seed-filling 


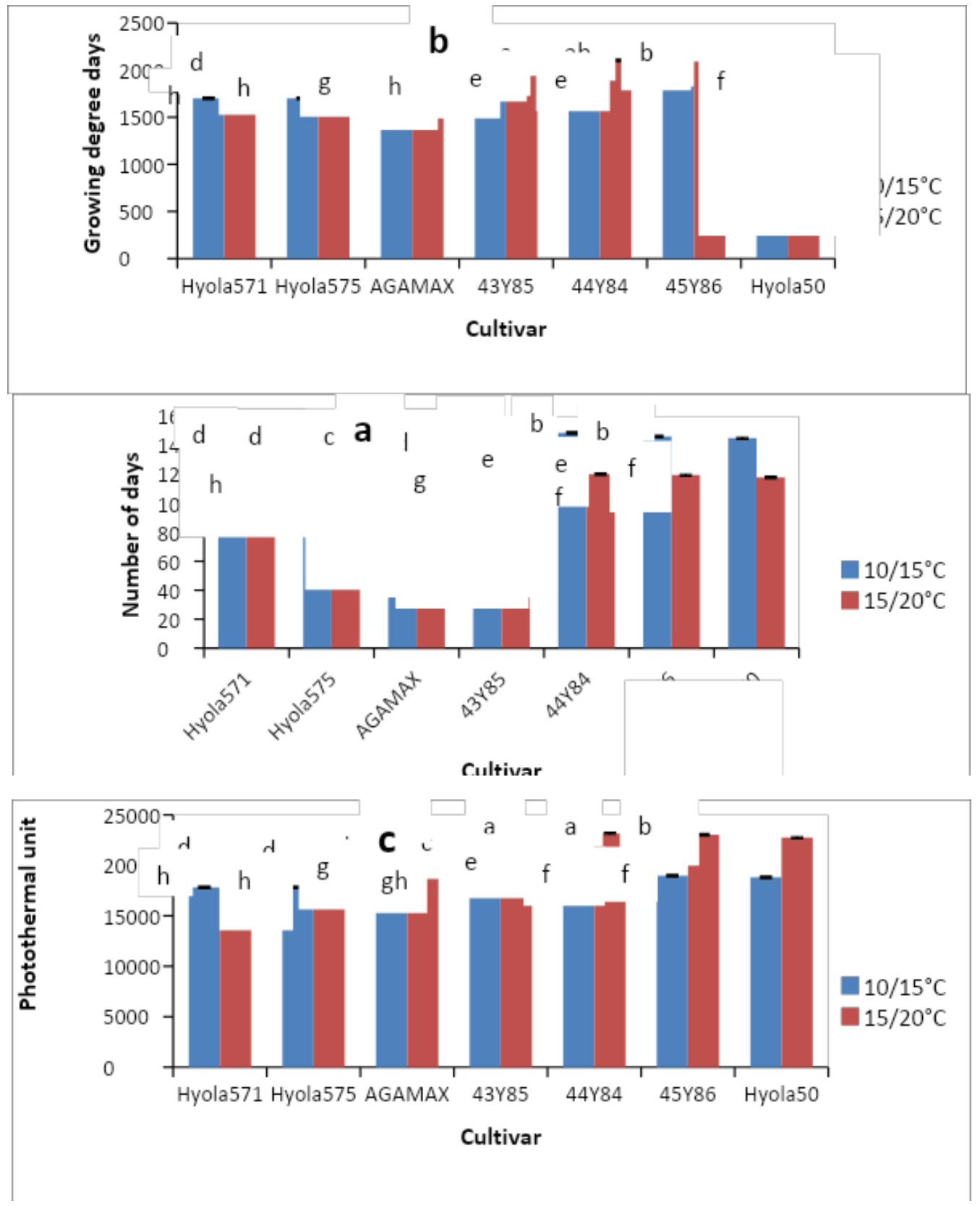

Figure 4 Effect of temperature on a) the number days, b) growing degree days $\left({ }^{\circ} \mathrm{Cd}\right)$ and c) photothermal units $\left({ }^{\circ} \mathrm{Cdh}\right)$ required from planting till physiological maturity of different genotypes. Values/ bars with the same alphabetical lettering do not differ significantly at $\mathrm{p}=0.05$

Simple relationships between DAP, GDD and PTU and plant components at budding, flowering and final harvest stages.

In general poor correlations were observed between physiological parameters (DAP, GDD and PTU) and plant components (Table 1). This was especially true for correlations between GDD as 
well as PTU with plant components. In both cases correlation coefficients did not show any trend with regard to plant growth stages (planting to budding, planting to flowering or planting to final harvest) and negative correlation were recorded for most plant components. This somewhat surprising result may be ascribed to the negative effects of the higher temperature regimes on most plant components while the higher temperature regime results in increases in GDD and PTU. Data from both temperature regimes were combined (because of the limited data points) to determine the relevant relationships and stronger correlations should be possible if enough data is available to do correlations for specific temperature regimes.

Correlations between the number of days after planting and plant components were generally positive and did show improving r-values with time (growth stage of the crop). The best correlations of $r=0.7259 ; r=0.6097$ and $r=0.5566$ were shown between number of days to final harvest and plant dry mass (DM), pod dry mass (PDM) and number of pods per plant (NPP). The implication of these results is that as number of days from planting to final harvest increase dry mass, number pods plant-1 and pods dry mass at final harvest of canola genotypes increase. Whereas, increased GDD and PTU decreased total above ground dry mass, number of pods plant-1 and pods dry mass at final harvest.

Table 1 Simple relationships between some physiological and morphological traits of Canola genotypes

\begin{tabular}{|c|c|c|c|}
\hline $\begin{array}{l}\text { DA } \\
\mathbf{P}\end{array}$ & BD & FL & FH \\
\hline $\mathbf{L A}$ & -0.2311 & 0.3922 & 0.4822 \\
\hline DM & -0.3582 & 0.4320 & $\begin{array}{l}0.7259 \\
*\end{array}$ \\
\hline $\begin{array}{l}\text { PD } \\
\text { M }\end{array}$ & 0.4884 & $\begin{array}{l}0.5332 \\
3 *\end{array}$ & $\begin{array}{l}0.6097 \\
*\end{array}$ \\
\hline $\begin{array}{l}\text { GD } \\
\text { D }\end{array}$ & 0.2860 & 0.0076 & $\begin{array}{l}- \\
0.1371\end{array}$ \\
\hline LA & 0.4926 & $\begin{array}{l}- \\
0.6316 \\
*\end{array}$ & $\begin{array}{l}- \\
0.5056 \\
*\end{array}$ \\
\hline$\overline{D M}$ & $\begin{array}{l}- \\
0.6227 * \\
6\end{array}$ & $\begin{array}{l}- \\
0.5947 \\
*_{-}\end{array}$ & $\begin{array}{l}- \\
0.6013 \\
*\end{array}$ \\
\hline $\begin{array}{l}\text { NPP } \\
\mathbf{P}\end{array}$ & $\overline{0.6329 *}$ & $\begin{array}{l}- \\
0.5750 \\
*\end{array}$ & $\begin{array}{l}- \\
0.5385 \\
*\end{array}$ \\
\hline $\begin{array}{l}\text { PD } \\
\text { M }\end{array}$ & $\overline{0.6329 *}$ & $\begin{array}{l}- \\
0.5750 \\
*\end{array}$ & $\begin{array}{l}- \\
0.5385 \\
*\end{array}$ \\
\hline $\begin{array}{l}\mathbf{P T} \\
\mathbf{U}\end{array}$ & 0.3257 & $\begin{array}{l}0.5835 \\
*\end{array}$ & $\begin{array}{l}- \\
0.2240\end{array}$ \\
\hline $\mathbf{L A}$ & $0.5085^{*}$ & $\begin{array}{l}- \\
0.0599\end{array}$ & $\begin{array}{l}- \\
0.5945 \\
*\end{array}$ \\
\hline
\end{tabular}


International Journal of Agriculture, Environment and Bioresearch

Vol. 5, No. 03; 2020

ISSN: $2456-8643$

\begin{tabular}{|llll|}
\hline $\mathbf{D M}$ & -0.4991 & - & - \\
& & 0.6113 & 0.6400 \\
& & $*$ & $*$ \\
\hline $\mathbf{N P P}$ & - & - & - \\
$\mathbf{P}$ & $0.5610^{*}$ & 0.5845 & 0.5989 \\
& & $*$ & $*$ \\
\hline $\mathbf{P D}$ & - & - & - \\
$\mathbf{M}$ & $0.5610^{*}$ & 0.5845 & 0.5989 \\
& - & $*$ & $*$ \\
\hline
\end{tabular}

*Significant at $5 \%$ probability. Number of days aGer planting (DAP), growing degree days (GDD), photothermal unit (PTU) from planting to budding (BD), planting to flowering (FL) and planting to final harvest(FH) and leaf area (LA), dry mass (DM), number of pods plant-1 (NPPP) and pod dry mass (PDM)

\section{CONCLUSIONS}

The results showed that increasing daily mean temperature from $12.5^{\circ} \mathrm{C}$ to $17.5^{\circ} \mathrm{C}$, on average, reduced the duration from planting to visible flower buds appearance by 5.79 days, flowering time by 10.38 days, time to beginning of seed-filling by 25.39 days and from planting to physiological maturity by 28.09 days. However, there were differences among the genotypes. These reductions in the duration may however change if plants were grown at different day lengths. Increased GDD and PTU due to higher mean daily temperatures however, decreased the total above ground dry mass, number of pods plant- 1 and pods dry mass at final harvest

In general, the results indicate that mid maturing genotypes, Hyola50, 45Y86 and 44Y84 and interestingly early maturing $43 \mathrm{Y} 85$ responded in similar manner during early growth stages, while Hyola 571, Hyola 575 and AGAMAX responded alike at both temperature regimes with respect to number of days, GDD and PTU. The mid-maturing genotypes and 43 Y 85 required more days, GDD and PTU from planting date to each of the growth stages studied. However at the physiological maturity, $43 \mathrm{Y} 85$, as classified, responded more like an early-maturing cultivar.

Therefore, it can be concluded that genotypes responded differently to night/day temperature regimes of $10 / 15^{\circ} \mathrm{C}$ and $15 / 20^{\circ} \mathrm{C}$ with respect to number of days, GDD and PTU from planting to budding, flowering, seed ripening and physiological maturity. Genotypes with intrinsic trait(s) for lateness tend to require more number of days, GDD and PTU from planting to these growth stages. Increases in night/day temperatures from $10 / 15^{\circ} \mathrm{C}$ to $15 / 20^{\circ} \mathrm{C}$ reduced number of days from planting date to all the growth stages and with exception of vegetative growth phase, increased GDD and PTU at all growth stages studied.

\section{REFERENCES}

Alocija EC, Ritchie JT. 1991. A model for the phenology of rice In: Hodges T. (Ed) predicting crop phenology.

CRC press Boca Raton FL. Pp 181-190. 
Vol. 5, No. 03; 2020

ISSN: $2456-8643$

Angadi SV, Cutforth HW, Miller PR, McConkey, Entz MH, Brabdt SA, Volkmar KM. 2000. Response of three Brassica species to high temperature stress during reproductive growth. Canadian Journal of Plant Science 56: 693-701.Anonymous. .2006. Canola production manual.

Bagnall D, King RW. 1991. Response of peanut (Arachis hypogeal) to temperature, photoperiod and irradiance In: Bertero etal.1999. photoperiod sensitive developmentphases in quinoa (chenopodum quinoa willd). Field Crops Research 60: 237-243.

Bertero HD, King RW, Hall AJ. 1999. Photoperiod-sensitive development phases in quinoa(Chenopodum quinoa willd). Field Crops Research 60: 231-243.

Birch CJ, Hammer GL, Rickert KG. 1998. Temperature and photoperiod sensitivity of development in five of maize (Zea mays ) from emergence to tassel initiation. Field Crops Research 55:93-107.

Burton WA, Flood RF, Norten RM, Field B, Potts DA, Robertson MJ, Salibury PA. 2008. Identification of variability in phenological responses in canola- quality Brassica juncea for utilization in Australia breeding programs. Australian Journal of Agricultural Research.59:847881.

Cao W, Moss DN. 1989. Day length effect on leaf emergence and phyllochron in wheat and barley. Crop Science 29:1021-1025.

Coolhaas C, Wormer TM. 1953. Developmental differences in rice plants in relation to photoperiodism.

Netherland Journal of Agricultural Science 1:207-216.

Craufurd PQ, Hauser IE, Dingkuhn M. 2003. photothermal responses of O. sativa and O. glaberima varieties and interspecific progenies from west Africa. Field Crops Research 83:313324.

Craufurd PQ, Qi A. 2001. Photothermal adaptation of sorghum (sorghum bicolor) in Nigeria. Agriculture, Forest and Meteorology 108:199-211.

Fischer RA. 1979. Growth and water limitation to dryland wheat yield in Australia: a physiological frame work.Journal of Ausralian Instittute of Agricultural Science. 45:83-94.

Fitter AH, Fitter RSR. 2002. Rapid changes in flowering time in British plants. Science 296 1689-1691.

Gallagher JN. 1979. Field studies of cereals leaf growth In; Initiation and expansion in relation to temperature and ontogeny. Journal of Experimental Botany 30: 625-636.

Gonzalez FG, Slafer GA, Marelles DJ. 2003. Floret development and spike growth as affected by photoperiod during stem enlongation in wheat. Field Crop Research: In press. 
Vol. 5, No. 03; 2020

ISSN: $2456-8643$

Harper FR, Berkenkamp B. 1975. Revised growth key for Brassica Campestris and B. Napus. Canadian Journal of Plant Science 55: 657-658.

Harper FR, Berkenkamp B. 1975. Revised growth key for Brassica Campestris and B. Napus. Canadian Journal of Plant Science 55: 657-658.

Hartel KA. 2012. Canola growth and development in central Western NSW. http//www.regional org.au/au/asa/2012/crop-production/8176_hartel.

Hepper FN. 2003. Phenological records of English garden plants in leeds (Yorkshine) and Richmond (Surrey) from 1946 to 2002. An analysis relating to global warming. Biodiversity and Conservation 12: 2503-2520.

Hofstra GJ, Hesketh JD, Myhre DL. 1977. A plastochron model for soybean leaf and stem growth. Canadian Journal Plant Science 57: 167-175.

IPCC . 2001. Climate change 2001; the scientific basis, contribution of working group to the third assessment report of intergovernmental panel on climate change. Cambridge University press, pp 103.

Kaesha N. 2009. Flowering phenology: An activity to introduce human \& environmental effects on plant reproduction. The American Biology Teacher 71(5).

Kasa GR, Kondra ZP. 1986. Growth analysis of spring type oilseed rape. Field Crop Research 14: 361-370.

Kernich GC, Halloran GM, Flood RG. 1996. Constant and interchanged photoperiod effects on the rate of development in barley (hordeum vulgare). Australian Journal of plant physiology 23:489-496.

Kiniry JR, Rosenthal WD, Jackson BS, hoogenbroom G. 1992. Predicting leaf development of crop plants In: Hodges T(Ed) predicting crop phenology. CRC.press Boca Raton FL. Pp 29-42.

Kirkegaard JA, Sprague SJ, Lilley JM, McCormick JI, Virgona JM, Morrison MJ. 2012. Physiological response of spring canola (Brassica napus) to defoliation in diverse environments. Field Crop Research 125:61-68.

Lineman AR. 1993. Phenological development in Bambara groundnut (Vigna subterranean) at constant exposure to photoperiods of 10 and 16h. Annals of Botany 71:445-452.

Matthews RB, Hunt. LA. 1994. GUMCAS: a model describing the growth of cassava (manihot esculent L.crantz). Field Crop Research 36: 69-84.

Mendham, NJ, Salisbury PA. 1995. Physiology; crop development, growth and yield. In; D.S Kimber and D.I McGregor (eds). Brassica oilseeds: production and utilization. Wallingford: CAB; PP 11-64. 
Vol. 5, No. 03; 2020

ISSN: $2456-8643$

Mills P. 1993. The effects of low temperatures on the germination and emergence of canola. Alberta Agriculture Farming for the Future Project 83-0036.

Morandi EN, Casano LM, Riggiado LM. 1988. Post flowering photoperiod effects on reproductive efficiency and seed growth in soybean. Field crops Research 18:227-241.

Morrison MJ, Stewart DW, McVetty PBE. 1992. Maximum area expansion rate and duration of summer rape leaves. Canadian Journal of plant Science 72:117-126.

Morrison MJ, Stewart DW, Mcvetty PBE. 1992. Maximum area, expansion and duration of summer rape leaves. Canadian Journal of Plant 72: 117-126.

Nanda R, Bhargava SC, Rawson HM. 1995. Effect of sowing date on rates of leaf appearance, final leaf numbers and areas in Brassica campestris, B. juncea, B napus and B. carinata . Field Crop Research 42: 125-134.

Paine CET, Matthews TR, Vogt DR, Purves D, Rees M, Hector A, Turnbull LA. 2012. ' 'How to fit nonlinear plant growth models and calculate growth rates: updates for ecologists". Methods in Ecology and Evolution 3:245

Pinrige AA, Down RJ, Borthwick HA. 1963. Photocontrol of growth and flowering of caryopteris. American Journal of Botany 50, 86-90.

Poggio SL, Satorre EH, Dethiou S, Gonzalez GM. 2005.Pod and seed numbers as a function of photothermal quotient during the seed set period of field pea (Pisum Sativum) crops. European Journal Agriculture 22:55-69.

Qaderi MM, Reid DM. 2005. Growth and physiological responses of canola (Brassica napus) to UV-B and CO2 under controlled environment conditions. Physiologia Plantarum 125: 247-259.

Qi A, Ellis RH, Keatinge JDH, Wheeler TR, Tarawali SA, Summerfield RJ. 1999. Differences in the effects of temperature and photoperiod on progress to flowering among diverse Muccuna spp. Journal of Agronomy \& Crop Science 182:249-255.

Qi A, Ellis RH, Keatinge JDH, Wheeler TR, Tarawali SA, Summerfield RJ. 1999. Differences in the effects of temperature and photoperiod on progress to flowering among diverse mucuna spp. Journal of Agronomy \& Crop Science 182: 249-258.

Richards RA. 1991. Crop improvement for temperature Australia: future opportunities. Field Crops Research 26: 141-169.

Ritchie JT, Ne Smith DJ.1991. Temperature and crop development In: Hanks RJ, Ritchie EJT,(eds)

Modelling plant and soil systems. Madison WI: American Society of Agronomy. PP 5-29.

Roberts EH, Summerfield RJ, Ellis RH, Qi A. 1993. Adaptation of flowering in crops to climate. Outlook Agriculture 22:105-110. 
Robertson MJ, Watkinson AR, Kirkegaard JA, Holland JF, Potter TD, Burton W, Walton GH, Moot DJ, Wratten N, Farre I, Asseng S. 2002. Environmental and genotypic control of time to flowering in canola and Indian mustard. Australian Journal of Agricultural Research 53: 793809.

Robertson, MJ. 2002. Understanding how environment and genotype determine time to flowering in canola and Indian mustard. www. Australianoilseeds.com.

Saarikko RA, Carter TR. 1995. Phenological development in spring cereals: responses to temperature and photoperiod under northern conditions. European Journal of Agronomy 5: 5970.

Siebert S, Ewert F. 2012. Spatio-temporal patterns of phonological development in Germany in relation temperature and day length. Agriculture and Forest Meteorology 152: 44-57.

Slafer GA, Rawson. HM. 1994. Sensitivity of wheat phasic development to major environmental factors: a re-examination of some assumptions made by physiologists and modelers. Australian Journal of Plant Physiology 21:393-426.

Slauenwhite KLI, Qaderi MM. 2013. Single and interactive effects of temperature and light quality on four canola cultivars. Journal of Agronomy and Crop Science 199: 286-298.

Soltani A, Robertson MJ, Mohammad-Nejad Y, Rahemi-Karizaki A. 2006. Modelling chickpea growth and development: Leaf production and senescence. Field Crop Research 99: 14-23.

Statistics Canada. 2010. 1999-2009 cereal and oil seeds review. Catalogue number CS22-007. Periodical statistics Canada. Ottawa.

Summerfield RJ, Roberts EH, Ellis RH, Lawn RJ. 1991. Towards the reliable prediction of time to flowering in six annual crops In: The development of simple models for fluctuating field environments. Experimental Agriculture 27: 11-31.

Tacarindua CRP, Shiraiwa T, Homma K, Kumagai E, Sameshima R. 2013. The effects of temperature on crop growth and yield of soybean in a temperature gradient chamber. Field Crops Research 154: 74-81.

Thomas RG. 1961. Correlation between growth and flowering in chenopodium amaranthicolor : initiation of leaf and bud primordial. Annals of Botany 25:138-151.

Vigil MF, Anderson RL, Beard WE. 1997. Base temperature and growing-degree-hour requirements for the emergence of canola. Crop Science 37: 844-849.

www.Australian oilseed federation 2013 